\title{
PENGENDALIAN DIRI SALAH SATU KETERAMPILAN KECERDASAN EMOSIONAL UNTUK MENINGKATKAN PRESTASI BELAJAR SISWA SEJAK DINI
}

\author{
Hidayat
}

Dosen Tetap Fakultas Tarbiyah IAIN Sulthan Thaha Saifuddin Jambi

\begin{abstract}
Learning process at school is a complex process and comprehensive. Many people said that someone has to have high Intelligence Quotient (IQ) in order to gain high achievement since intelligence is potential asset which is making easier to study and produce optimum high learning achievement.

As a matter of fact, in studying and learning process at school, some of the students cannot attain learning achievement equivalent with the Intelligence Quotient. There are some students with high Intelligence Quotient but the learning achievements are low. In the other hand, there are some students with low Intelligence Quotient can attain high learning achievement. Therefore, Intelligence Quotient is not the only factor which is deciding someone's success. Another factor which influences someone's success is Emotional Intelligence (EI). Emotional Intellegence is someone's ability to manage his/her emotional life with intelligence, keep the appropriateness of emotion and its expression through selfconsciousness' skill, self-control, self-motivation, emphatic, and social skill.
\end{abstract}

Keyword: learning achievement, self-control

\section{A. Pendahuluan}

Pendidikan adalah suatu usaha atau kegiatan yang dijalankan dengan sengaja, teratur dan berencana dengan maksud mengubah atau mengembangkan perilaku yang diinginkan. Sekolah sebagai lembaga formal merupakan sarana dalam rangka pencapaian tujuan pendidikan tersebut. Melalui sekolah, siswa belajar berbagai macam hal.

Dalam pendidikan formal, belajar menunjukkan adanya perubahan yang sifatnya positif sehingga pada tahap akhir akan didapat keterampilan, kecakapan dan pengetahuan baru. Hasil dari proses belajar tersebut tercermin dalam prestasi belajarnya. Namun dalam upaya meraih prestasi belajar yang memuaskan dibutuhkan proses belajar.

Proses belajar yang terjadi pada individu memang merupakan sesuatu yang penting, karena melalui belajar individu mengenal lingkungannya dan menyesuaikan diri dengan lingkungan disekitarnya. Menurut Irwanto (1997:105) belajar merupakan proses perubahan dari 
belum mampu menjadi mampu dan terjadi dalam jangka waktu tertentu. Dengan belajar, siswa dapat mewujudkan cita-cita yang diharapkan.

Belajar akan menghasilkan perubahan-perubahan dalam diri seseorang. Untuk mengetahui sampai seberapa jauh perubahan yang terjadi, perlu adanya penilaian. Begitu juga dengan yang terjadi pada seorang siswa yang mengikuti suatu pendidikan selalu diadakan penilaian dari hasil belajarnya. Penilaian terhadap hasil belajar seorang siswa untuk mengetahui sejauh mana telah mencapai sasaran belajar inilah yang disebut sebagai prestasi belajar.

Proses belajar di sekolah adalah proses yang sifatnya kompleks dan menyeluruh. Banyak orang yang berpendapat bahwa untuk meraih prestasi yang tinggi dalam belajar, seseorang harus memiliki Intelligence Quotient (IQ) yang tinggi, karena inteligensi merupakan bekal potensial yang akan memudahkan dalam belajar dan pada gilirannya akan menghasilkan prestasi belajar yang optimal. Menurut Binet dalam buku Winkel (1997:529) hakikat inteligensi adalah kemampuan untuk menetapkan dan mempertahankan suatu tujuan, untuk mengadakan penyesuaian dalam rangka mencapai tujuan itu, dan untuk menilai keadaan diri secara kritis dan objektif.

Kenyataannya, dalam proses belajar mengajar di sekolah sering ditemukan siswa yang tidak dapat meraih prestasi belajar yang setara dengan kemampuan inteligensinya. Ada siswa yang mempunyai kemampuan inteligensi tinggi tetapi memperoleh prestasi belajar yang relatif rendah, namun ada siswa yang walaupun kemampuan inteligensinya relatif rendah, dapat meraih prestasi belajar yang relatif tinggi. Itu sebabnya taraf inteligensi bukan merupakan satu-satunya faktor yang menentukan keberhasilan seseorang, karena ada faktor lain yang mempengaruhi.

Menurut Goleman (2000:44), kecerdasan intelektual (IQ) hanya menyumbang $20 \%$ bagi kesuksesan, sedangkan $80 \%$ adalah sumbangan faktor kekuatan-kekuatan lain, diantaranya adalah kecerdasan emosional atau Emotional Quotient (EQ) yakni kemampuan memotivasi diri sendiri, mengatasi frustasi, mengontrol desakan hati, mengatur suasana hati (mood), berempati serta kemampuan bekerja sama.

Dalam proses belajar siswa, kedua inteligensi itu sangat diperlukan. IQ tidak dapat berfungsi dengan baik tanpa partisipasi penghayatan emosional terhadap mata pelajaran yang disampaikan di sekolah. Namun biasanya kedua inteligensi itu saling melengkapi. Keseimbangan antara IQ dan EQ merupakan kunci keberhasilan belajar siswa di sekolah (Goleman, 2002). Pendidikan di sekolah bukan hanya perlu mengembangkan rational intelligence yaitu model pemahaman yang lazimnya dipahami siswa saja, melainkan juga perlu mengembangkan emotional intelligence siswa . 
Hasil beberapa penelitian di University of Vermont mengenai analisis struktur neurologis otak manusia dan penelitian perilaku menunjukkan bahwa dalam peristiwa penting kehidupan seseorang, EQ selalu mendahului intelegensi rasional. EQ yang baik dapat menentukan keberhasilan individu dalam prestasi belajar membangun kesuksesan karir, mengembangkan hubungan suami-istri yang harmonis dan dapat mengurangi agresivitas, khususnya dalam kalangan remaja (Goleman, 2002 :17).

Tidak dapat dipungkiri, bahwa siswa yang memiliki IQ rendah dan mengalami keterbelakangan mental akan mengalami kesulitan, bahkan mungkin tidak mampu mengikuti pendidikan formal yang seharusnya sesuai dengan usia mereka. Namun fenomena yang ada menunjukan bahwa tidak sedikit siswa dengan IQ tinggi yang berprestasi rendah, dan ada banyak siswa dengan IQ sedang yang dapat mengungguli prestasi belajar siswa dengan IQ tinggi. Hal ini menunjukan bahwa IQ tidak selalu dapat memperkirakan prestasi belajar seseorang.

Kemunculan istilah kecerdasan emosional dalam pendidikan, bagi sebagian orang mungkin dianggap sebagai jawaban atas kejanggalan tersebut. Teori Daniel Goleman, sesuai dengan judul bukunya, memberikan definisi baru terhadap kata cerdas. Walaupun EQ merupakan hal yang relatif baru dibandingkan IQ, namun beberapa penelitian telah mengisyaratkan bahwa kecerdasan emosional tidak kalah penting dengan IQ (Goleman, 2002:44).

Menurut Goleman (2002 : 512), kecerdasan emosional adalah kemampuan seseorang mengatur kehidupan emosinya dengan inteligensi (to manage our emotional life with intelligence); menjaga keselarasan emosi dan pengungkapannya (the appropriateness of emotion and its expression) melalui keterampilan kesadaran diri, pengendalian diri, motivasi diri, empati dan keterampilan sosial. Berdasarkan uraian di atas, dalam artikel ini penulis membatasi pada kajian tentang pengendalian diri sebagai salah satu keterampilan dalam kecerdasan emosional untuk meningkatkan prestasi belajar siswa.

\section{B. Pengertian Prestasi Belajar}

Prestasi belajar tidak dapat dipisahkan dari perbuatan belajar, karena belajar merupakan suatu proses, sedangkan prestasi belajar adalah hasil dari proses pembelajaran tersebut. Bagi seorang siswa belajar merupakan suatu kewajiban. Berhasil atau tidaknya seorang siswa dalam pendidikan tergantung pada proses belajar yang dialami oleh siswa tersebut.

Menurut Logan dkk. (dalam Sia Tjundjing, 2001:70) belajar dapat diartikan sebagai perubahan tingkah laku yang relatif menetap sebagai hasil pengalaman dan latihan. Senada dengan hal tersebut, Winkel8 
(1997:193) berpendapat bahwa belajar pada manusia dapat dirumuskan sebagai suatu aktivitas mental atau psikis yang berlangsung dalam interaksi aktif dengan lingkungan, yang menghasilkan perubahanperubahan dalam pengetahuan dan nilai sikap. Perubahan itu bersifat relatif konstan dan berbekas.

Belajar tidak hanya dapat dilakukan di sekolah saja, namun dapat dilakukan dimana-mana, seperti di rumah ataupun dilingkungan masyarakat. Irwanto (1997:105) berpendapat bahwa belajar merupakan proses perubahan dari belum mampu menjadi sudah mampu dan terjadi dalam jangka waktu tertentu. Sedangkan menurut Mudzakir (1997:34) belajar adalah suatu usaha atau kegiatan yang bertujuan mengadakan perubahan di dalam diri seseorang, mencakup perubahan tingkah laku, sikap, kebiasaan, ilmu pengetahuan, keterampilan dan sebagainya.

Di dalam belajar, siswa mengalami sendiri proses dari tidak tahu menjadi tahu, karena itu menurut Cronbach (Sumadi Suryabrata,1998:231) Belajar yang sebaik-baiknya adalah dengan mengalami. Dalam mengalami itu proses pembelajaran tersebut pelajar mempergunakan pancainderanya. Pancaindera tidak terbatas hanya indera pengelihatan saja, tetapi juga berlaku bagi indera yang lain.

Belajar dapat dikatakan berhasil jika terjadi perubahan dalam diri siswa, namun tidak semua perubahan perilaku dapat dikatakan belajar karena perubahan tingkah laku akibat belajar memiliki ciri-ciri perwujudan yang khas (Muhibbidin Syah, 2000:116) antara lain :

1. Perubahan Intensional

Perubahan dalam proses berlajar adalah karena pengalaman atau praktek yang dilakukan secara sengaja dan disadari. Pada ciri ini siswa menyadari bahwa ada perubahan dalam dirinya, seperti penambahan pengetahuan, kebiasaan dan keterampilan.

2. Perubahan Positif dan aktif

Positif berarti perubahan tersebut baik dan bermanfaat bagi kehidupan serta sesuai dengan harapan karena memperoleh sesuatu yang baru, yang lebih baik dari sebelumnya. Sedangkan aktif artinya perubahan tersebut terjadi karena adanya usaha dari siswa yang bersangkutan.

3. Perubahan efektif dan fungsional

Perubahan dikatakan efektif apabila membawa pengaruh dan manfaat tertentu bagi siswa. Sedangkan perubahan yang fungsional artinya perubahan dalam diri siswa tersebut relatif menetap dan apabila dibutuhkan perubahan tersebut dapat direproduksi dan dimanfaatkan lagi. 
Perubahan-perubahan tersebut akan tampak dalam prestasi belajar yang dihasilkan oleh siswa melalui pertanyaan, persoalan atau tugas yang diberikan oleh guru. Prestasi belajar tersebut, dimanfaatkan siswa untuk mengetahui kemajuan-kemajuan yang telah dicapainya dalam belajar.

Marsun dan Martaniah dalam Sia Tjundjing (2000:71) berpendapat bahwa prestasi belajar merupakan hasil kegiatan belajar, yaitu sejauh mana peserta didik menguasai bahan pelajaran yang diajarkan, yang diikuti oleh munculnya perasaan puas bahwa ia telah melakukan sesuatu dengan baik. Hal ini berarti prestasi belajar hanya bisa diketahui jika telah dilakukan penilaian terhadap hasil belajar siswa.

Menurut Poerwodarminto (Mila Ratnawati, 1996 : 206) yang dimaksud dengan prestasi adalah hasil yang telah dicapai, dilakukan atau dikerjakan oleh seseorang. Sedangkan prestasi belajar itu sendiri diartikan sebagai prestasi yang dicapai oleh seorang siswa pada jangka waktu tertentu dan dicatat dalam buku rapor sekolah.

Untuk meraih prestasi belajar yang baik, banyak sekali faktor yang perlu diperhatikan, karena di dalam dunia pendidikan tidak sedikit siswa yang mengalami kegagalan. Kadang ada siswa yang memiliki dorongan yang kuat untuk berprestasi dan kesempatan untuk meningkatkan prestasi, tapi dalam kenyataannya prestasi yang dihasilkan di bawah kemampuannya.

\section{Faktor-Faktor Yang Mempengaruhi Prestasi Belajar Siswa}

\section{Pengaruh Pendidikan dan Pembelajaran Unggul}

Seorang secara genetis telah lahir dengan suatu organisme yang disebut inteligensi yang bersumber dari otaknya. Struktur otak telah ditentukan secara genetis, namun berfungsinya otak tersebut menjadi kemampuan umum yang disebut inteligensi, sangat dipengaruhi oleh interaksi dengan lingkungannya (Semiawan, C, 1997). Pada kala bayi lahir ia telah dimodali 100 - 200 milyar sel otak dan siap memproseskan beberapa trilyun informasi. Cara pengelolaan inteligensi sangat mempengaruhi kualitas manusianya, tetapi sayang perlakuan lingkungan dalam caranya tidak selalu menguntungkan perkembangan inteligensi yang berpangaruh terhadap kepribadian dan kualitas kehidupan manusia. Ternyata dari berbagai penelitian bahwa pada umumnya hanya kurang lebih 5\% neuron otak berfungsi penuh (Clark, 1986).

Lingkungan pendidikan dan berbagai pusat pelatihan serta tempat kerja kita kini juga dipengaruhi oleh lingkungan global yang merupakan berbagai pengaruh eksternal dalam dinamika berbagai aspek kehidupan di dunia, Lingkungan global yang mengadung pengertian tereksposnya kita oleh kehidupan komunitas global menuntut adaptasi masyarakat kita pada kondisi global dan pada gilirannya menuntut adaptasi individu untuk bisa 
bertahan di masyarakat di mana ia hidup. Interface antar berbagai stimulus lingkungan melalui interaksi untuk mewujudkan aktualitasasi diri individu secara optimal dalam masyarakat di mana ia hidup dan juga aktualisasi daerah pada masyarakat yang lebih luas, nasional maupun global, inilah yang harus menjadi perhatian pengelola ataupun atasan atas perlakuan subjek SDM, dalam hal kita, para guru dalam perlakuannya terhadap peserta didik. Interaksi yang terjadi dalam prilaku anak-anak kita. Namun secara reciprocal (timbal balik) perlakuan yang diterjadikan adalah cermin kehidupan masyarakat di mana ia hidup.

Menghadapi era global di masa yang akan datang, diharapkan kesadaran tentang reformasi pendidikan memenuhi kondisi masa depan yang dipersyaratkan (necessary condition to be fullfield). Kurun waktu milenium ke 3 dari proses kehidupan manusia sudah berjalan, dan abad ke-21 serta abad ke-22 ini bukan saja merupakan abad-abad baru, melainkan juga peradaban baru. Hal ini dikarenakan betapapun mengalami krisis moneter, Indonesia akan terkena juga oleh restrukturisasi global dunia yang sedang berlangsung. Restrukturisasi dunia, yang terutama ditandai oleh berbagai perubahan dalam bidang ekonomi, sosial, politik dan aspek kehidupan lain, mempengaruhi setiap insan manusia, laki, perempuan, anak di negara berkembang maupun di negara maju, tidak terkecuali negara Indonesia, dan terutama berdampak terhadap orientasi pendidikan.

\section{Perkembangan dan Pengukuran Otak}

Sebagaimana tadi dikatakan, maka cara penggunaan sistem kompleks dari proses pengelolaan otak ini sebenarnya sangat menentukan inteligensi maupun kepribadian dan kualitas kehidupan yang dialami seorang manusia, serta kualitas manusia itu sendiri. Untuk meningkatkan kecerdasan anak maka produksi sel neuroglial, yaitu sel khusus yang mengelilingi sel neuron yang merupakan unit dasar otak, dapat ditingkatkan melalui berbagai stimulus yang menambah aktivitas antara sel neuron (synaptic activity), dan memungkinkan akselerasi proses berfikir (Thompsn, Berger, dan Berry, 1980 dalam Clark, 1986). Dengan demikian inteligensi manusia dapat ditingkatkan, meskipun dalam batasbatas tipe inteligensinya.

Secara biokimia neuron-neuron tersebut menjadi lebih kaya dengan memungkinkan berkembangnya pola pikir kompleks. Juga banyak digunakan berkembangnya aktivitas "Prefrontal cortex" otak, sehingga terjadi perencanaan masa depan, berfikir berdasarkan pemahaman dan pengalaman intuitif, Prefrontal cortex yang terutama tumbuh pada ketika anak berumur duabelas sampai enambelas tahun mencakup juga kemampuan melihat perubahan pola ekstrapolasi kecendrungan hari ini ke masa depan; regulasi diri serta strategi "biofeedback" dan meditasi; berfikir sistem analisis;yang merupakan aspek-aspek bentuk tertinggi 
kreativitas serta memiliki kepekaan sosial, emosional maupun rasional (Goodman, 1978, dalam Clark, 1986). Sifat-sifat manusia ini banyak terkait dengan sifat-sifat inisiatif dan dorongan mencapai kemandirian dan keunggulan.

Otak dewasa manusia tidak lebih dari $1,5 \mathrm{~kg}$, namun otak tersebut adalah pusat berfikir, perilaku serta emosi manusia mencerminkan seluruh dirinya (selfhood), kebudayaan, kejiwaan serta bahasa dan ingatannya. Descartes pusat kesadaran orang, ibarat saisnya, sedangkan badan manusia adalah kudanya. Meskipun kemudian ternyata, bahwa perilaku manusia juga dipengaruhi oleh ketidaksadarannya (freud dalam Zohar, 2000:39), kesadaran manusia yang oleh Freud disebut rasionya merupakan kemampuan umum yang mengontrol seluruh perilaku manusia. Berbagai penelitian kemudian membuktikan bahwa kemampuan rasional tersebut biasa diukur dengan IQ (Intelligence Quetient). Meskipun kini terbukti bahwa orang memiliki lebih dari satu inteligensi menurut teori Gardner ada 8 (teori Multiple Intelligence), ukuran yang disebut IQ mengukur kemampuan umum yang bersifat tunggal masih sering dipakai untuk menandai kemampuan intelektual dan prestasi belajar. Ternyata bahwa otak tersebut masih menyimpan berbagai kemungkinan lain.

"Celebral Cortex" otak dibagi dalam dua belahan otak yang disambung oleh segumpal serabut yang disebut "corpus callosum". Belahan otak kanan menguasai belahan kiri badan, sedangkan belahan otak kiri menguasai belahan kanan badan. Respons, tugas dan fungsi belahan kiri dan kanan berbeda dalam menghayati berbagai pengalaman belajar, sebagaimana seorang mengalami realitas secara berbeda-beda dan unik. Belahan otak kiri terutama berfungsi untuk merespons terhadap hal yang sifatnya linier, logis, teratur, sedangkan yang kanan untuk mengembangkan kreativitasnya, mengamati keseluruhan secara holistik dan mengembangkan imaginasinya. Dengan demikian ada dua kemungkinan cara berfikir, yaitu cara berfikir logis, linier yang menuntut satu jawaban yang benar dan berfikir imaginatif multidimensional yang memungkinkan lebih dari satu jawaban.

3. Kecerdasan Emosional (Emosional Intellegensi)

a. Prestasi belajar di sekolah sangat dipengaruhi oleh kemampuan umum kita yang diukur oleh IQ, IQ yang tinggi meramalkan sukses terhadap prestasi belajar. Namun IQ yang tinggi ternyata tidak menjamin sukses di masyarakat (Segal, 1997:14). Pada permulaan tahun sembilan puluhan berbagai penelitian menunjukkan (Segal, 1997:5) bahwa diinspirasi oleh berbagai psikolog humanis seperti Maslow, Rollo May, Carl Rogers yang sangat memperhatikan segi-segi subyektif (perasaan) dalam perkembangan psikolog, eksplorasi tentang emosi telah menunjuk pada sumber-sumber emosi (Segal, 1997, Goleman, 1995). Ternyata bahwa emosi selain mengandung persaan yang dihayati seseorang, juga 
mengandung kemampuan mengetahui (Menyadari) tentang perasaan yang dihayati dan kemampuan bertindak terhadap perasaan itu. Bahkan pada hakekatnya emosi itu adalah impuls untuk bertindak. Goleman menyatakan bahwa selain rational mind, seorang memiliki an emotional main yang masing-masing diukur oleh IQ dan EQ dan bersumber masingmasing dari head dan heart. kedua kehidupan mental tersebut, meskipun berfungsi dengan cara-caranya sendiri, bekerjasama secara sinergis dan harmonis.

b. Homo sapiens yang memiliki neocortex (otak depan) yang merupakan sumber rasio, yaitu otak depan, terdiri dari pusat-pusat yang memahami dan mendudukan apa yang diamati oleh alat dria kita. Dalam evolusi tentang pengtahuan kemampuan organisma, ternyata bahwa penanjakan kehidupan manusia dalam peradaban dan kebudayaan adalah kerja neocortex yang ternyata juga menjadi sumber kemampuan seseorang untuk perencanaan dan strategi jangka panjang dalam mempertahankan hidup (Goleman, 1995:11). Perkembangan ini menjadi otak memiliki nuansa terhadap kehidupan emosional seseorang. Struktur lymbic (sumsum tulang belakang) menghidupkan perasaan tentang kesenangan dan keinginan seksual, yaitu emosi yang mewujudkan sexual passion. Namun keterkaitan sistem lymbic tersebut dengan neocortex menumbuhkan hubungan dasar ibu-anak, yang menjadi landasan untuk unit keluarga dan commitment jangka panjang untuk membesarkan anak (spesi yang tidak dimiliki organisma ini seperti binatang melata, tidak memiliki kasih sayang) dan sering membunuh dan / atau menghancurkan anaknya sendiri. Masa anak dan masa belajar panjang (long childhood) bersumber dari saling keterhubungan neuron-neuron dalam 'pabrik' otak ini.

c. Amygdala adalah neuron yang mewujudkan struktur keterhubungan di atas brainstem dekat dasar dari limbic ring (cincin sumsum tulang belakang antara emosi dan rasio). Amygdala adalah tempat penyimpanan memori emosi. Joseph Le Doux, neoroscientist dari Center for Neural Scince New York University menemukan peran penting amygdala dalam otak emosional. Amygdala menerima input langsung melalui alat dria dan memberikan signal kepada neocortex, namun juga dapat memberikan respons sebelum tercatat di neocortex. Jadi ada kemungkinan respons manusia sebelum ia berfikir. (Sumber : website Direktorat Pembinaan TK dan SD - Departemen Pendidikan Nasional) (www.idp-europe.org/).

Hambatan belajar dan perkembangan sebagaimana dapat dilihat di atas, hambatan belajar dan perkembangan dapat terdiri dari banyak bentuk. Di masa lalu, pendekatan-pendekatan pengajaran anak yang berkelainan ditentukan oleh diagnosis medis yang diberikan kepada 
mereka. Dengan pendekatan tersebut, anak-anak dengan diagnosis yang serupa harus diajar dengan cara yang sama.

Sekarang kita menyadari bahwa walaupun pembelajaran akan dipengaruhi oleh kecacatan, tetapi ada faktor-faktor lain yang lebih penting. Faktor-faktor tersebut dapat terletak dalam pengalaman tergantung pada:

1) Lingkungan, termasuk sikap terhadap anak-anak pada umumnya dan terhadap anak tertentu karena: lingkungan yang tidak responsif dan kurang stimulasi. Pemahaman atau kesalahpahaman guru akan proses pembelajaran. Isi, pendekatan pengajaran dan materi pembelajaran Faktor-faktor lingkungan umum yang berkaitan dengan kondisi sosial, ekonomi dan politik di masa lalu dan sekarang.

2) Faktor-faktor dalam diri anak termasuk: Keingintahuan Motivasi Inisiatif, interaksi dan komunikasi Kompetensi sosial Kreatifitas Temperamen Dorongan untuk belajar dan gaya belajar Kemampuan

3) Hakikat dan tingkat kecacatan kecacatan, jika ini merupakan bagian dari

gambaran tentang anak itu.

Dari poin-poin di atas kita dapat melihat bahwa hambatan belajar dapat terjadi juga ketika tidak ada kecacatan terlibat di sana. Kita juga dapat melihat kompleksitas dan multiplisitas kondisi pembelajaran itu. Diharapkan dengan mempertimbangkan semua faktor ini akan meningkatkan pemahaman kita tentang keunikan setiap individu anak. Apa yang harus kita ingat adalah bahwa menghadapi keunikan dapat menjadi tantangan yang besar dalam sebuah kelas dan khususnya dalam kelas yang besar. Konsep "hambatan belajar dan perkembangan" menarik perhatian kita pada kesulitan dan tantangan yang dapat muncul di setiap kelas, kesulitan-kesulitan yang dapat dihadapi oleh semua anak. Namun, konsep ini juga membantu kita menyadari besarnya implikasi dari hambatan belajar yang disebabkan oleh faktor sensori, motorik, kognitif, emosional dan lingkungan. Ini membantu kita menyadari bahwa, misalnya, penguasaan Braille oleh seorang anak tunanetra tidak mengatasi semua hambatan akibat ketunanetraannya.

\section{Pengertian, Tujuan dan Strategi Pengendalian Diri}

Menurut Logue, A.W. dalam Nurihsan (2005:69) self control as the choice of the large, more delayed outcome. Logue dalam memaknai pengendalian diri lebih menekankan pada pilihan tindakan yang akan memberikan manfaat dan keuntungan yang lebih luas dengan cara menunda kepuasan sesaat (choice are delay gratification and immediate gratification). 
Lebih lanjut, Nurihsan (2005:70) menjelaskan pengendalian diri dalam bahasa umum adalah tindakan menahan diri untuk tidak melakukan perbuatan-perbuatan yang akan merugikan dirinya di masa kini maupun di masa yang akan datang. Kerugian itu bentuknya macammacam, mungkin sakit badan, sakit hati, bangkrut, gagal dalam mencapai cita-cita, dan tidak dipercaya oleh orang lain.

Adapun dalam bahasa agama, pengendalian diri itu adalah upaya untuk menjaga diri dari perbuatan-perbuatan yang dilarang oleh agama. Sebagaimana Allah memerintahkan kita untuk menjaga diri kita dan keluarga kita dari api neraka. Api neraka di sini dapat ditafsirkan sebagai sesuatu yang menyakitkan, merugikan, dan menghancurkan kehidupan manusia.

Untuk dapat mengendalikan diri, seseorang hendaknya mampu mengendalikan hati, sebab hati sangat berkuasa atas wawasan, pikiran, dan tindakan seseorang (Ary Ginanjar Agustian, 2001:220). Sebagai contoh: ketika kemarahan memuncak, suasana hati seringkali bergolak tak terkendali. Tekanan yang kian menumpuk terus membengkak hingga mencapai titik batas, dan terus bertumpuk, mendekati titik kritis yang tak tertahankan. Akibatnya, persoalan kecil yang biasanya tidak mnimbulkan apa-apa, akan berubah menjadi persoalan serius yang sangat mengesalkan hati, dan membuat seseorang sangat resah atau gusar.

Tujuan utama mengendalikan diri adalah memperoleh keberhasilan, kemajuan, dan kebahagiaan. Dilihat dari sudut agama, tujuan pengendalian diri adalah menahan diri dalam arti yang luas. Menahan diri dari belenggu nafsu duniawi yang berlebihan dan tidak terkendali, atau nafsu batiniah yang tidak seimbang. Kesemuanya itu, apabila tidak diletakkan pada porsi yang benar akan mengakibatkan suatu ketidakseimbangan hidup yang akan berakhir pada kegagalan. Dorongan nafsu fisik atau batin secara berlebihan akan menghasilkan sebuah rantai belenggu yang akan menutup asset yang paling berharga dari manusia, yaitu "god-spot". God-spot adalah kejernihan hati dan pikiran manusia yang merupakan sumber-sumber suara hati yang selalu memberikan bimbingan maha penting untuk keberhasilan, kemajuan, dan kebahagiaan manusia.

Berikut ini adalah strategi pengendalian diri:

1. Ingat terus kepada Tuhan Yang Maha Esa yang senantiasa mengatur diri kita;

2. Berfikir terlebih dahulu dengan menggunakan akal yang jernih mengenai keuntungan dan kerugian bagi diri kita sebelum melakukan sesuatu;

3. Bertanya pada hati nurani kita yang paling dalam akan kebaikan dan keburukan yang ditimbulkan dari perbuatan kita; 
4. Bersabar apabila kita terkena musibah;

5. Kita bersabar dalam mengerjakan sesuatu yang diperintahkan Allah;

6. Kita bersabar dalam menghindari sesuatu yang dilarang Allah;

7. Kita bersyukur apabila mendapat kenikmatan; dan

8. Kita empati pada orang lain.

\section{E. Fakta Peran Pengendalian Diri Dalam Meningkatkan Prestasi Belajar Siswa}

Bukti ilmiah tentang peran kecerdasan emosi melalui keterampilan pengendalian diri dalam meningkatkan prestasi belajar siswa ditulis oleh Daniel Goleman (dalam Nurihsan, 2005:71-72), ia seorang ahli dan peneliti tentang kecerdasan emosi. Anak-anak berusia empat tahun di Taman Kanak-Kanak Stanford disuruh masuk ke dalam sebuah ruangan seorang demi seorang, sepotong marshmallow (manisan putih yang empuk) diletakkan di atas meja di depan mereka, "kalian boleh makan manisan ini jika mau, tetapi kalau kalian memakannya sekembali saya kesini, kalian berhak mendapatkan sepotong lagi".

Sekitar empat belas tahun kemudian, sewaktu anak-anak itu lulus sekolah lanjutan tingkat atas (SMA), anak-anak yang dahulu langsung memakan manisan dibandingkan dengan anak-anak yang mampu mengendalikan diri sehingga mendapatkan dua potong menunjukkan perkembangan sebagai berikut. Mereka yang langsung memakan manisan dibandingkan mereka yang tahan menunggu (mampu mengendalikan diri), cenderung tidak tahan menghadapi stress, mudah tersinggung, mudah berkelahi, dan kurang tahan uji dalam mengejar cita-cita mereka.

Para peneliti menemukan hasil yang mengejutkan dengan munculnya efek yang betul-betul tak terduga dari anak-anak yang mampu mengendalikan diri. Anak-anak yang mampu menahan diri dalam uji manisan, dibandingkan dengan yang tidak tahan, memperoleh nilai yang lebih tinggi dalam uji masuk ke perguruan tinggi.

Ketika anak-anak dari Taman Kanak-Kanak Stanford itu tumbuh menjadi dewasa dan bekerja, perbedaan-perbedaan di antara mereka semakin mencolok. Di penghujung usia duapuluhan, mereka yang lulus uji manisan ketika kanak-kanak, tergolong orang yang sangat cerdas, berminat tinggi, dan lebih mampu berkonsentrasi. Mereka lebih mampu mengembangkan hubungan yang tulus dan akrab dengan orang lain, lebih handal dan lebih bertanggung jawab, dan pengendalian dirinya lebih baik saat menghadapi frustrasi.

Sebaliknya, mereka yang langsung memakan manisan sewaktu berusia empat tahun, saat usia mereka hampir tiga puluh tahun, kemampuan kognitif mereka kurang dan kecakapan emosinya sangat lebih 
rendah dibanding kelompok yang tahan uji. Mereka lebih sering kesepian, kurang dapat diandalkan, lebih mudah kehilangan konsentrasi, dan tidak sabar menunda kepuasan dalam mengejar sasaran. Bila menghadapi stress, mereka hampir tidak mempunyai toleransi atau pengendalian diri. Mereka tidak luwes dalam menanggapi tekanan, bahkan sering mudah meledak dan ini cenderung menjadi kebiasaan.

Kisah anak-anak dan manisan mengandung pelajaran yang lebih mendalam tentang kerugian akibat ketidakmampuan mengendalikan diri, yang merupakan salah satu keterampilan dalam kecerdasan emosi. Bila individu berada di bawah kekuasaan impuls, agitasi, dan emosionalitas, kemampuan berfikir dan bekerja bisa menjadi merosot sekali. Uji manisan ini juga membuktikan pentingnya ibadah puasa yang diperintahkan oleh Allah SWT.

Berdasarkan uraian diatas, dapat difahami bahwa orang yang memiliki kecerdasan emosi diperkirakan akan mampu mengahadapi tantangan, godaan, dan rintangan. Mereka juga diperkirakan akan mampu berkonsentrasi dalam bekerja. Mereka lebih mampu mengembangkan hubungan yang tulus dan akrab dengan orang lain, lebih handal dan lebih bertanggung jawab, dan pengendalian dirinya lebih baik saat menghadapi frustrasi.

\section{F. Penutup}

Kecerdasan emosional merupakan salah satu faktor yang ada pada diri siswa (kenyataan internal) yang mempunyai peranan penting dalam menentukan prestasi belajar. Namun demikian, banyak faktor lain yang dapat mempengaruhi prestasi belajar dan semuanya saling terkait. Dengan demikian hubungan antara kecerdasan emosional dan prestasi belajar dipengaruhi juga oleh faktor-faktor lain, yaitu ambisi, kenyataan eksternal dan usaha.

Kecerdasan emosional dapat dilatih dan dapat dimanfaatkan untuk meningkatkan prestasi belajar, karena kecerdasan emosional terbentuk karena adanya keselarasan pikiran dan perasaan. Penelitian di Amerika Serikat menunjukkan bahwa tingkat kecerdasan emosional yang tinggi berhubungan dengan nilai yang baik pada mata pelajaran English Basic Writing. Penelitian di Indonesia menunjukkan bahwa tingkat kecerdasan rasional (Intellegensi Quotient) dan aspek pengendalian diri (Self Controll) dari kecerdasan emosional yang berperan secara signifikan dengan prestasi belajar. Prestasi belajar dipengaruhi oleh berbagai faktor yang saling berkaitan sehingga kecerdasan emosional saja tidak dapat menemukan prestasi belajar. 


\section{Daftar Pustaka}

Goleman, Daniel. (2000). Emitional Intelligence (terjemahan). Jakata: PT Gramedia Pustaka Utama.

Goleman, Daniel. (2000). Working With Emotional Intelligence (terjemahan). Jakarta: PT. Gramedia Pustaka Utama.

Irwanto. (1997). Psikologi Umum. Jakarta : PT. Gramedia Pustaka Utama.

Mudzakir, Ahmad. (1997). Psikologi Pendidikan. Bandung: Pustaka Setia.

Nurihsan, Juntika. 2005. Strategi Layanan Bimbingan dan Konseling. Bandung: Refika Aditama

Ratnawati, Mila. (1996). Hubungan antara Persepsi Anak terhadap Suasana Keluarga, Citra Diri, dan Motif Berprestasi dengan Prestasi Belajar pada Siswa Kelas V SD Ta'Miriyah Surabaya. Jurnal Anima Vol XI No. 42.

Suryabrata, Sumadi. (1998). Psikologi Pendidikan. Jakarta: PT. Raja Grafindo Persada .

Syah, Muhibbin. (2000). Psikologi Pendidikan dengan Suatu Pendekatan baru. Bandung: PT. Remaja Rosdakarya.

Tjundjing, Sia. (2001). Hubungan Antara IQ, EQ, dan QA dengan Prestasi Studi Pada Siswa SMU. Jurnal Anima Vol.17 no.1

Winkel, WS (1997). Psikologi Pendidikan dan Evaluasi Belajar. Jakarta: Gramedia.

Wirawan, Sarlito. (1997). Psikologi Remaja. Jakarta: PT. RajaGrafindo Persada 